\title{
THE STUDY OF HR PRACTICES IN SIMES DURING THE BUFFETED COVID-19 TIMES IN INDIA
}

KEY WORDS: Human

Resource Management, HR practices, SME's, COVID -19,

\section{Divya Bajpai*}

\section{Dr. Rachna Gandhi}

(Phd,Scholar) B K School Of Business Management Gujarat University, Ahmedabad. *Corresponding Author

(Assistant Professor) KS School of Business Management Gujarat University, Ahmedabad

The catastrophe brought by COVID - 19 a global pandemic is a ruthlessly evident fact, which is not only confined to one sphere of earth but seems omnipresent. Small, medium enterprise in India are facing the wrath of the situation and blatantly insensitive are employers, employees and the daily wage earners to the situation. The manufacturing sector of SMEs is at the knell bell of submergence, Human Relation practices are soft solution to the sinking boat of SMEs and will help in rebounding of human relation trust at workplace. SMEs being the most important part of economy, their bouncing back can help the dwelling national operations. Innovative HR practices will boost employee's morale and will wipe the tears of labourers. This paper therefore will help in bottoming the situation of recurrent losses witnessed by SMEs and HR practices will help in promoting, encourage thinking of kick start of the exit strategies. SMEs that are in the war of survival and will definitely prove the scourge of covid-19 a boon for Indian economy.

\section{Introduction}

COVID -19 pandemic is much confabulated issue which is no less than any unpropitiously vicious circle bending down the economy to a deplorable state of insanity. India SMEs are at mercy of 2020, facing the war of survival and being severely mutilated. The time is such where the entrepreneurs/owners of SMEs have to put a tremendous effort to fight back bluntly in order to save themselves from getting perished. Where daily wage earners are getting jobless and pathetically ruined after leaving the land of "karma" and migrating insanely. Though Ministry of Labour and Employment,2020 has requested "Companies to avoiding employee termination, wage reduction which could deepen the crises and hamper their morale." Such devastated happening has made call on HR manager and department to work prudently and save the firm from the backlash mockery caused by pandemic 2020 .

First time the Rich, the mighty and the poor are facing the scourge of survival and death. Impact of the pandemic disease has hit hard employees, SMEs specially manufacturing sector that were already reeling under a magnitude of constraints were according to Index of Industrial Production, May 2020 contracted to $16.7 \%$. Manufacturing sector output slumped $20 \%$ in March, while electricity generation shrank almost $6.8 \%$, as per data. (Press release, dated 12.05.2020, MoSPI). According to UNCTAD, India's trade impact due to coronavirus outbreak could be about US\$ 348 million. (The Economics Times Mar 05, 2020) The manufacturing sector of electrotonic is under major threat due to significant supply of it being from China and what already has arrived need high level of sanitization. "Tragedy is such that worker are not ready to touch any device from China". Says Rajoo Goel, Secretary General, Electronic Industries Association of India (ELCINA). (The Economics Times,26/02/2020). No wonder, the days are going to get tougher for SMEs, supporting this section Anil Bhardwaj, Secretary General, Federation of Indian Micro and Small \& Medium Enterprises (FISME), says the import of APIs (Active Pharmaceutical Ingredient) is critical for pharma industry and its shortage will cripple pharma manufacturing." But not to worry the best is yet to come "India will now be looked upon as a short to long term option. India is poised to gear up for production in the short-term with the low-end and mediumend products that are expected to benefit well" Rakesh Kumar, Director General, Export Promotion Council for Handicrafts (EPCH). (The Economics Times, 27/02/2020) which might turn the table of India's slowing down economy.

Need for the study: India SMES which are getting arrested in pandemic will comeout reviving the economy with a bang. Though this being a time a jolts and fear which has pounced on SMEs is full of uncertainties and vulnerabilities but this is no less than a boon when schemes like "Atmanirbhar Bharat "and Rs 20-lakh-crore stimulus package that might bring the positive side of manufacturing sector of SMEs in India, encouraging Indian made local product and substituting the market demand. The real role plays of HR or the owners of SMEs will be to brainstorm the existing manpower rather than getting self-brainwashed with fear, encouraging them financially and providing surety of security.

\section{Review of literature}

SMEs in India have occupied a place of strategic importance in the economy and so will keep on being a good source of Nations building. (Sarita Satpathy et.al., 2017). SMEs contribution towards export accounted to be $48 \%$ of Indian export, employing nearly $40 \%$ of Indian workforce population, with $29 \%$ contribution toward country's GDP and overall employment generation of 11.10 crores. (MSME Annual Report 2018-19 and Economic Survey, 2019-2020). Evidentially, SMEs hold a burgeoning importance to the Nations growth, which were mushrooming in a myriad before the wrath of COVID-19. The table below shows the recent changes done in the definition of MSMEs, which is now based on investment and turnover of enterprise.

Table No 1: A New Revised Definition of MSMEs

\begin{tabular}{|c|c|c|c|}
\hline Enterprise & \multicolumn{2}{|c|}{ Existing Criteria for MSME } & $\begin{array}{c}\text { Revised Criteria } \\
\text { for MSME }\end{array}$ \\
\cline { 2 - 4 } & $\begin{array}{c}\text { Manufacturin } \\
\text { g Investment } \\
\text { in Plant \& } \\
\text { Machinery }\end{array}$ & $\begin{array}{c}\text { Service } \\
\text { Investment in } \\
\text { equipment's }\end{array}$ & $\begin{array}{c}\text { Manufacturing } \\
\text { and Service } \\
\text { Composite } \\
\text { Criteria } \\
\text { Investment and } \\
\text { Turnover }\end{array}$ \\
\hline Micro & $\begin{array}{c}\text { Up to Rs. 25 } \\
\text { lakhs }\end{array}$ & $\begin{array}{c}\text { Up to Rs. 10 } \\
\text { lakhs }\end{array}$ & $\begin{array}{c}\text { Investment }<1 \mathrm{cr} \\
\text { and Turnover }<5 \\
\text { cr }\end{array}$ \\
\hline Small & $\begin{array}{c}\text { Above Rs. 25 } \\
\text { lakhs up to Rs. } \\
5 \text { crore }\end{array}$ & $\begin{array}{c}\text { Above Rs. 10 } \\
\text { lakhs up to Rs. } \\
2 \text { crore }\end{array}$ & $\begin{array}{c}\text { Investment }<10 \mathrm{cr} \\
\text { and Turnover }< \\
50 \mathrm{cr}\end{array}$ \\
\hline Medium & $\begin{array}{c}\text { Above Rs. 5 } \\
\text { crore up to Rs. } \\
10 \text { crore }\end{array}$ & $\begin{array}{c}\text { Above Rs. 2 } \\
\text { crore up to Rs. } \\
5 \text { crore }\end{array}$ & $\begin{array}{c}\text { Investment }<20 \\
\text { cr and Turnover }< \\
100 ~ c r\end{array}$ \\
\hline
\end{tabular}

(Source: Ministry of Micro, Small \& Medium Enterprises, Atmanirbhar Presentation Part-1, Business including MSMEs 135-2020) 
The Government of India on 01.06.2020 decided for further upward revision of the MSME Definition. Medium Enterprises, now it will be Rs. 50 Crore of investment and Rs. 250 Crore. (PIB-June 3, 2020)

HR practices in SMEs, demonstrates the importance of organization in SMEs, it is cautioned that the failure of SMEs could lead to a situation of unemployment and the consequent social tensions (Saini \& Budhwar, 2008). The role of HR in enhancing firm's efficiency and effectiveness is well established (Upasna A Agarwal and Sumi Jha 2015). Human Resource practices within SMEs play a very crucial role and will help in enhancing the understanding of SMEs effectively (Hung et.al, 2016). Various evidences have pointed out of having HRM practices lapping with performance (Wright, et.al.2005). HR practices having direct impact on the Performance of SMEs. Performance is all the more depended upon the labour and employee of the organization. SMEs being labour intensive, the presences of skilled labour is of utmost importance. Somehow there has been a lack of emphasis on human as a resource in HR in SMEs (Puplampu, 2005). Employee in SMEs need to be constantly motivated which generally in SMEs they tend to be, employees demand innovation in their ways of working is generally the stream SMEs have been working since long (Curado, 2018). Omolo, J.W (2013) has very well defined that employees voice and compensation practices in SMEs are rarely heard topics whereas recruitment, selection, training and development are a predictor of organizational performance of SMEs and which is true, stated by researches found various literatures. Transforming the working of SMEs by Digitalization of HR practices has been a buzz and having digital techniques in organization will provide safe and healthy working environment (Pranjali Singh, 2017), with easy in access to information and easy in utilization of best available resources.

Mapping the changes in HR practices during COVID-19 times: It is a challenge which all the SMEs are witnessing. The 101-year-old Spanish Influenza, that cost over 50 million lives, failed to teach the world about the 'Humane' in Human Resources, despite warnings from the World Economic Forum, in collaboration with the Harvard Global Health Institute, and what Covid-19 doing. The aftermath of the new rampant and virulent strain of the Novel Coronavirus, (COVID-19) is soon going to change the way one looks at businesses as well as employment. In these trying time the HRM which could bring back the Humane factor back to distressful working conditions of sinking SMEs which are still reeling under the constraints of time. The worthful decision taken by the HR department /owner of the company can impact the life of employees and the entire workforce in a nutshell.

Working conditions provided by the owner/HR department of every SME is expected to fulfil something that has been lately acknowledged as a grave concern, it is the issue of mental health, the cause of which has almost always been overlooked. HR management should ensure a smooth flow of operations across all departments of SMEs while ensuring the productivity metrics of their employees (Chitra Balasubramanian, 2020). It's a time to adopt task-oriented strategy, thinking about alternative course of actions and their likely outcomes. https://www.hrduo.com/ (2020) stress on a New Modal of working where business and owners are needed to look beyond the standard list of criteria. Traditionally, the focus was on matching the knowledge, skill and ability of person to a job requirement (Bruystegem, et.al., 2008) but now new learning, work with dedication and honesty and have vision for better future. Technology is a new future engaging talent, allows flexibility to work at owns space.

Motivational programs are a need of an hour creating an environment in which entrepreneur, the root of an SME must be motivated and provide managerial and technical knowledge, with wide array of skills. Promotional activities suiting all the learning needs to assess the values of employee's efficacy to perform wide and right. (Arvind Kumar,2020). Motivation is easily surfaced when welldesigned training programs are coherent to it. Before Covid19 affected SMEs, HR managing issues like recruitment, training and selection, staff promotion and retention, wage and salary negotiation, T\&D, etc. were an extensive burden on an SME owner but post Covid-19 these all core HR activities are well comprehended with the help of technology.

Training Programs must be provided to acquire a competitive edge and opportunities for SMEs and awareness of new tecno-economic tools and how low-cost cloud solutions and leadership skills can be facilitated among SMEs (Arvind Kumar,2020). The Human Resource department should ensure that all the employees have capable work on laptops to complete their day-to-day tasks.

e-Practices are a breathable option. The SMEs are facing the scourge of downfall during this time because SMEs presumes that adoption of technology in the business execution is a costly affair, however, it's not always like that. Furthermore, technology like HR software has always made the functioning of enterprises better and hassle-free. Likewise, SMEs which are using HR software to monitor and track new job applications, designing payrolls for existing as well as for new employees, chalking vacancies, performing background checks of potential candidates, and perhaps most importantly allow job applicants to apply online. (Financial Express, 28/5/2018). If all this could have been done before lamenting then this backlashing time wouldn't have been harder on SMEs.

Self-Reliant India Movement of Govt of India provides a Package to cater to various sections of society including SMEs and labourers. It is time to become vocal for our local products and make them global. SMEs are the one to be pledge upon for being what India needs at times of such crises. The Funds leverage upon SMEs will help to expand its size as well as capacity and will encourage SMEs to get listed on main board of Stock Exchanges. (Atmanirbhar Bharat Part 1: Businesses including MSMEs Government of India 13.05.2020)

International Pandemics Researches Table No 2: International Studies on Pandemics and Epidemics

\begin{tabular}{|l|l|l|l|l|l|}
\hline Authors & Countries & Epidemics/pandemics & Effects & Stream & Observations \\
\hline $\begin{array}{l}\text { M Warner \& G O M } \\
\text { Lee, 2005 }\end{array}$ & $\begin{array}{l}\text { Hong } \\
\text { Kong }\end{array}$ & SARC & $\begin{array}{l}\text { Level of } \\
\text { employment, } \\
\text { unemployment } \\
\text { and labour } \\
\text { market }\end{array}$ & HRM practices & $\begin{array}{l}\text { It killed many fewer victims } \\
\text { than feared. Post economy } \\
\text { bounced back, creating } \\
\text { more job and industries. } \\
\text { HRM practices were in dire } \\
\text { need. Mitigating losses on } \\
\text { lay -offs and redundancy } \\
\text { rife. Encouraged higher } \\
\text { level of sanitization. }\end{array}$ \\
\hline
\end{tabular}




\begin{tabular}{|c|c|c|c|c|c|}
\hline \begin{tabular}{|l|} 
David E. Bloom and \\
David Canning 2013
\end{tabular} & Global & Various epidemics & $\begin{array}{l}\text { Economy, and } \\
\text { health sector }\end{array}$ & $\begin{array}{l}\text { Global health } \\
\text { practices }\end{array}$ & $\begin{array}{l}\text { Isolation and quarantine as } \\
\text { self defence system, } \\
\text { Policies influenced by short } \\
\text { term political consideration. } \\
\text { Economic impact } \\
\text { exacerbates, protective } \\
\text { behaviour invoked to } \\
\text { improve health } \\
\text { management. }\end{array}$ \\
\hline $\begin{array}{l}\text { World Health } \\
\text { Organization } 2018\end{array}$ & Global & $\begin{array}{l}\text { All pandemics and } \\
\text { epidemics }\end{array}$ & $\begin{array}{l}\text { Animals and } \\
\text { humans }\end{array}$ & Community Health & $\begin{array}{l}\text { Predictions of new viruses, } \\
\text { reason for spread mobility, } \\
\text { lack of sanitization, hygiene } \\
\text { and restless organisation. } \\
\text { Emphasized on increasing } \\
\text { health security and } \\
\text { sanitization. }\end{array}$ \\
\hline $\begin{array}{l}\text { Ayoung Lee and } \\
\text { Joonmo Cho } 2016\end{array}$ & Korea & \begin{tabular}{|l} 
Middle \\
East Respiratory \\
Syndrome (MERS)
\end{tabular} & $\begin{array}{l}\text { Labour market } \\
\text { vulnerability }\end{array}$ & $\begin{array}{l}\text { HRM, labour } \\
\text { management }\end{array}$ & \begin{tabular}{|l|} 
Ensured preparedness, \\
effecting young age group, \\
to ensure economic \\
measure, enhanced medical \\
services. "Existing U shape \\
curve of labour market \\
turned to J shape after \\
outbreak" \\
\end{tabular} \\
\hline $\begin{array}{l}\text { Stefane M Kabene, } \\
\text { Carole Orchard, } \\
\text { John M Howard, } \\
\text { Mark A Soriano and } \\
\text { Raymond Leduc, } \\
2006 .\end{array}$ & Global & $\begin{array}{l}\text { All pandemics and } \\
\text { epidemics }\end{array}$ & Health care & HRM practices & $\begin{array}{l}\text { HRM initiative are required, } \\
\text { more extensive research on } \\
\text { new HR, policies and } \\
\text { practices to benefit the } \\
\text { world at the time of crises } \\
\text { HR professionals to make a } \\
\text { positive contribution which } \\
\text { can effectively handle the } \\
\text { depleting situations }\end{array}$ \\
\hline $\begin{array}{l}\text { Gagandeep Kang, } \\
\text { George Perkovich, } \\
\text { Shruti Sharma, } 2019\end{array}$ & India & Infectious disease spread & $\begin{array}{l}\text { Public health } \\
\text { and } \\
\text { development, }\end{array}$ & $\begin{array}{l}\text { Community } \\
\text { management }\end{array}$ & $\begin{array}{l}\text { Emphasis on skewed data } \\
\text { collection model, proper } \\
\text { surveillance. Working with } \\
\text { international standard, } \\
\text { development of epidemic } \\
\text { ecological model for } \\
\text { diseases. }\end{array}$ \\
\hline
\end{tabular}

The above table no2 is tabulated pictured to show that there have been various researches on previously and yearly occurred contagions creating havoc. Researches mentioned above shows that there has been a continuous emphasis on healthy and sanitization but all have to be achieved with sheer preparedness. The role of HRM becomes crucial here for framing policies and practices having futuristic approach that can be designed for the upcoming outbreaks like COVID-19.

\section{Objective of Study:}

1. To study the handling of labour and employee issues/problems by HR in SMEs

2. To study the impact of lockdown on HR practices in SMEs

\section{Research methodology}

The study is conceptual in nature as it tries to explore various HR practices in SMEs during the buffeted covid-19 times in India. The annotation aims to study the role of $\mathrm{HR}$ in handling current and aftermath crises caused by Pandemic Covid-19 and analysis its direct impact on internal and external factors affecting SMEs In India with especial reference to manufacturing sector. The study being exploratory in nature is supported by relevant literature cited. The paper presents research work and it is theoretical in a sense that its issues have not yet been studied in an empirical setting. The research work is based on poised understanding of various phases of HR practices followed by SMES to stand strong and manage crises. In addition, previous researches and secondary data helped in establishing a connection and helped in framing conclusions and analysis.

\section{Discussion and Findings}

|www.worldwidejournals.com|
India SMEs concern during covid-19 The biggest worry of SMEs during the lockdown phase is of course of labour and employee's migration. Manufacturing Sector of SMEs employees $11.10 \mathrm{cr}$ as workforce according to National Sample Survey (NSS) 73rd round conducted during the period 2015-16, making a hefty number household depended on 0.33 million small and 0.005 million medium units. (MSMEs Annual Report, 2018-19). This sector also accounts for $1 / 3$ of Indian manufacturing output and $48.10 \%$ of export during 2018-19, (Press Information Bureau GOI, July 2019) contributing to $29 \%$ of the national GDP and forming $90 \%$ of the total industrial units but all this was when the Indian manufacturing units were mushrooming in a myriad with a good statistical figure, making themselves concert, but after the pandemic backlashed manufacturing sector of SMEs so hard that they might not be able to recuperate easily.

Labour, employees and bleeding SMEs in the greatest depression of all time, China not so wanted gift COVID-19 is not less than a lurking foe, ringing the bell of deaths and worriers. At this time bringing back the workers/labourers is very critical and need trust on their safety at work place Therefore ILO has issued two guidance documents for creating safe and effective return-to-work conditions during the COVID-19 pandemic on 22 May 2020. It is the infuriating picture of labour market where $1 / 6$ of young people have stopped working since the onset of the COVID-19 pandemic while those who remain employed have seen their working hours cut by 23 percent (ILO,2020). Migrant workers, particularly semi and unskilled workers, have returned in large numbers to their hometowns. The movement of materials, as well as fuels and people, has by and large come 
to an abrupt standstill. Only a small fraction of workforce is at work, due to which the manufacturing sector is at halt. With uncertainties of manpower which will be a constraint with SMEs estimating $70 \%$ of the workforce migration already to their hometown due to income, food, etc loss for their livelihood. (Economic Times 25/04/2020).

To bring HR practices innovatively is a dire need of SME units where recruitment is absolutely a shutdown case and managing people to work from home, making labours stay and stick to work has to be made a NEW NORMAL. The power of Creating New Normal, Convincing, Cooperating and Communicating are practices to be followed and should be imbibing by HR in SMEs.

\section{Table no 2: SMES Real Situation}

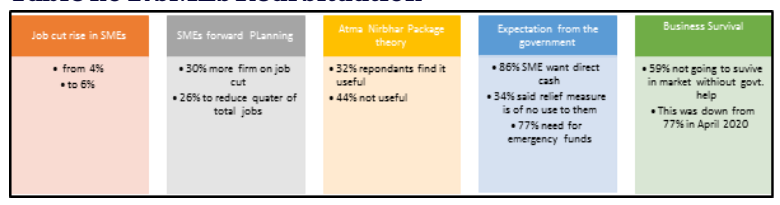

(Source: Survey was conducted by Skoch Consultancy Services in association with Federation of Indian Micro and Small \& Medium Enterprises (FISME), Bhartiya Vitta Salahkar Samiti and Tax Law Educare Society. (Economic Times 29/05/2020)

The above table no2 brings a vivid picture of 200 survey SMEs in National Capital Region after the relief package of government was announced. The above picture shows the dilemma of SMEs after the package was announced showing that SMEs might still feel helpless.

\section{Figure 3: It's a vicious circle of SMEs in COVID-19 times}

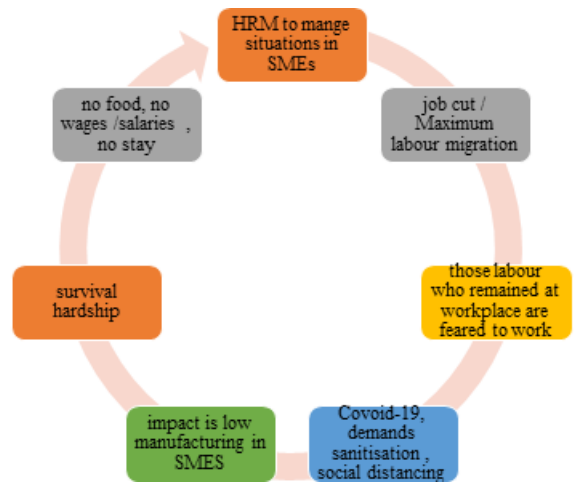

(Source:Scholar's finding)

Above figure 3, says it will be a challenge to convince staff to return to work or to hire new staff, all this will impact negatively on productivity and quality of manufacturing, further adding it to financial concern. Though recently "SMEs have started to consider workforce-related solutions, with the help of ongoing communication networks with workers (including those who returned to their home state), setting up buddy systems (potentially with retired employees and/or client technical staff), engagement with industrial training institutes." (UNIDO,2020). With the above guideline laid down the work of HR department can be made easy to build a convincing, reliable conversation programs for bring back the workforce with more power.

HR Practices need a makeover and provide innovative and well-developed communication programs when it comes to manufacturing sector of SMEs. Its now a virtual ride of $\mathrm{HR}$ of how-to mange HR practices during COVID-19. HR are the hidden horses managing employees, encouraging them to the core, revamping their role and performing well. Counselling on board, creating short term goals which are easily achievable will definitely bring positive changes in workforce. Digitalized more and more of HR practices can do wonders. "The concept behind e-HR is to create organizationa 1 culture that enhances the working knowledge of employees by adding value to the business." (Pooja Dixit.2017).

e-Training during the COVID-19 period can be a game changer. If not at workplace then at home, virtual training of machines, building of parts, manufacturing process through online classes (Atman Nirbhar scheme. 2020) will turn the tables. While various attempts have been made to implement e-learning and training for SMEs (Mullins et.al, 2007) then "A well trained workforce will lead to satisfaction, motivated workers will help the management to maintain a good relationship between management and workers. It will reduce industrial lockouts, strikes, etc." (Swetha H.S, 2019). A very well said statement that "For production employees, analysis of training is not done because their training needs are known. Employees that have been in company for 30-40 yrs. it has been noticed that if they don't meet the standard with a new machine, then concern changes are made and training is given to them. Company can't allow a machine to run at 50\% efficiency." (Andree Roy et.al.,2019). Such elearning and e-training can be a smart resolution to such locking times where employees who lacks in performance of such output can achieve it through such training programs organized by owner or HR of the SMEs.

Figure.4: Steps in a business recovery process in the wake of the COVID-19 pandemic

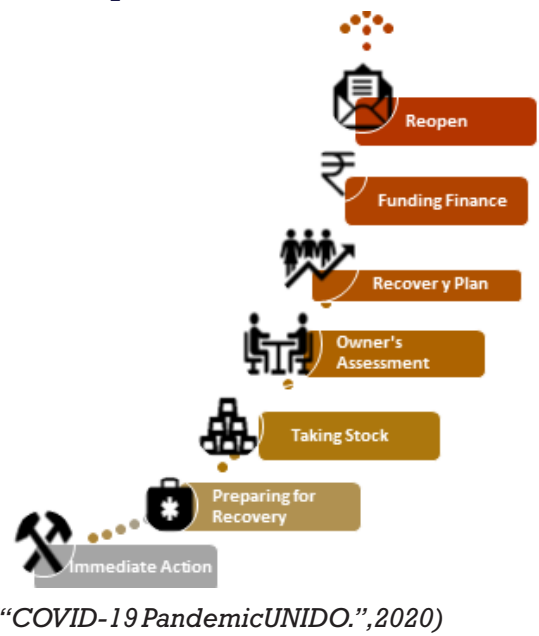

Source:(“COVID-19 PandemicUNIDO.,,2020)

The above figure4. lays down the step by step business recovery programs in wake of COVID-19 by UNDIO. All the above steps have been asked in the question form by the SMEs for the revival.

Immediate Action: Is the Staff having the option to come back to work? Are there any deterrents for them to come back to work (particularly in the event that they originate from another area)? What are the present guidelines that apply to movements? Is there anything you can do to assist them with coming back to work?

Preparing for recovery: By any chance that you can't legitimately proceed onward with your production or requests have been dropped by your clients, would you be able to drop contracts that you have set with your providers? Did you contact your supplier about installment plans? (Request rescheduling because of the interference that kept you from utilizing the provisions they had delivered.). Do you have to delay buying supplies until further notice?

Taking stock: Did you decide accessibility of cash? Do you have adequate cash, (for example, liquid money, cash 
available with bank, recoverable cash due with client) to cover dues debt and payable in the following months? If necessary, can your stock be effectively changed over into money to pay your obligations?

Owners Assessment: SMEs are simply managed by the owner or rely wholly and solely upon the proprietor and coparcener regardless of whether functions that are delegated to assigned managers. SMES that are managed by the owner whether small or medium adequately rely upon the administration done by their proprietors.

Recover Plans: Should you and would you be able to embrace new innovations and procedures? Will this influence the equipment need? Assuming this is the case, would it be a good idea for you to sell old or purchase new equipment? Did you consider renting hardware you need? Which are the best times to install new equipment's? Can you lessen the operating cost and overheads expenses?

Funding and financing: Can you stand strong and revive your business? Can the money be found in the event that it would be affordable (for instance from returns obtained over the next12-36 months? Did you complete the forecasts for income and losses and misfortune?

Reopen: Employee's inquiries, areas of questions, hardware and equipment question, stock, promoting, evaluating and different issues related inquiry to be advanced before reviving the unit.

The above all are the related steps to be answered well before reopening the firm and standing concrete yet flexible with double energy synergizing with Government aids

\section{CONCLUSION}

"SMEs need to change their way of doing business operations in order to contain the spread of COVID -19" said, Nitin Gadkari union minister MSME. This industry has to show a paradigm shift in operating business by ensuring safety of human resource from arranging food shelter to maintaining social distance norms, moving ahead combating Chinese's market to boomeranging of Indian products. Joining hands with government, promoting recent government schemes like Atmanirbhar 2020 and making the country self-reliant thereby boosting Indian trade affairs. The owner, the whole and sole of SMEs or the existing HR department of the firm should ensure full use of technology by digitalizing HR practices, to work efficiently and effectively, reducing the mundane task of manual job to trimming unnecessary and underutilized manpower. Integration of various departments to work coherently and to have a ready actionable data plan for unforeseen crises. Preparedness is the only solution to keep losses at bay. In SMEs specially, manufacturing sector the low conversion rate of employees is often a result of unskilled labour, that needs to be upgraded. HR practices should lay emphasis on e-Training, e-learning, usage of machine learning (ML), video learning (VL), artificial intelligence (AI) for better advancement in operations and organizational output. This will eventually help the SMEs to get back to work from this phase. This is indeed the best time for SMEs to think dynamically and of having their own company websites for being easily approachable. HR of the SMEs should be very precise and clear while communicating the message to the employees of company for better decision making and building confidence in the employees. Lastly for SMEs lamentable will be the decisions only pondered and tranquillizers will be the decisions performed perfectly before this tough time ought to belittle SMEs terribly.

\section{REFERENCES:}

1. Aatmanirbhar Presentation Part-1 Business including MSMEs 13-5-2020.pdf http://164.100.117.97/Wr iteReadData/userf iles/Aatmanirbhar\%20Present ation \%20Part-1\%20Business \%20including\%20MSMEs\%2013-5-2020.pdf
2. Arvind Kumar, (2020). Social entrepreneurship key to MSMEs realization in the post COVID 19WORLD?. SMEs world April 2020 page 12-15.

3. Ayoung Lee and Joonmo Cho (2016). The impact of epidemics on labor market: identifying victims of the Middle East Respiratory Syndrome in the Korean labor market, International Journal for Equity in Health (2016) 15:196

4. Bruystegem, Van K., Van de Woestyne, M., Dewettinck, K. (2008). Human Resource Challenges for Growing SME. How Flemish Entrepreneurs Attract, Develop and Retain Employees. Leuven: Vlerick Leuven Gent Management School.

5. Chitra Balasubramanian, 2020. Building immunity in employees: mental health and productivity. SMEs world April 2020 page 16-17.

6. COVID-19 and Enterprises Briefing Note [No. 20] Published:29 May 2020

7. Curado, C. (2018) 'Human resource management contribution to innovation in small and medium-sized enterprises: A mixed methods approach', Creativity and Innovation Management,Vol.27 No. 1,pp.79-90.

8. David E. Bloom and David Canning, (2013). Epidemics and Economics Harvard School of Public Health PGDA Working Paper No. 9: http://www.hsph.harvard.edu/pgda/working.htm

9. Pooja Dixit, (2017). Digitalisation- An Emerging Trend in Human Resource Practices.3(4),5.http://www.onlinejournal.in/IJIRV3I4/368.pdf

10. Economic Survey 2019-2020.https://www.indiabudget.gov.in/economicsur vey/

11. Economic Times 25/04/2020. msmes-see-potential-return-of-lockdown-inthe-future-as-a-major-challenge-UNIDO-survey.https://economictimes.ind iatimes.com/small-biz/sme-sector/msmes-see-potential-return-oflockdown-in-the-future-as-a-major-challenge-unido-survey/articleshow/75 369859.cms?from $=\mathrm{mdr}$

12. Economic Times $29 / 05 / 2020.44 \%$ MSMEs feel stimulus package not good enough. https://economictimes.indiatimes.com/small-biz/sme-sector/44msmes-feel-stimulus-package-not-good-enough/articleshow $/ 76082351 . \mathrm{cm}$ $\mathrm{s}$

13. Gagandeep Kang, George Perkovich, Shruti Sharma,(2019), India's Pandemic Preparedness and Response,December 06,2019 https://carnegieindia.org/ 2019/12/06/india-s-pandemic-preparedness-and-response-event-7276

14. Government of India, ministry of statistics and programme implementation national statistical office May 12,2020. Embargo advisory http://mospi.nic.in /sites/default/files/iip/IIP_PR_Mar_120502020.pdf

15. HR Challenges in MSME India -HR in MSME India. (2020). HR Consultancy Services in Delhi - Human Resource for Startups and SMEs. https://headsupcorporation.com/blog/identifying-and-resolving-hrchallenges-faced-by-msme-units-in-india/

16. Hung,Y.T., Cant, M. C., \&Wiid, J.A. (2016) 'The importance of human resources management for small businesses in South Africa', Problems and Perspectives in Management, Volume 14, Issue 3,2016

17. ILO:More than one in six young people out of work due to COVID-19. (2020). http://www.ilo.org/global/about-the-ilo/newsroom/news/WCMS 745879/ lang--en/index.htm.

18. Impact-of-COVID-19-on-Indian-Economy-FICCI-2003.pdf.(2020), http://ficci.in/spdocument/23195/Impact-of-COVID-19-on-IndianEconomy-FICCI-2003.pdf.

19. India's Manufacturing Reels from the Impact of Covid-19 | Unido. (2020) https://www.unido.org/stories/indias-manufacturing-reels-impact-covid19.

20. M Warner \& G O M Lee, (2005). Epidemics, Labour-Markets and Unemployment: The impact of SARS on human resources management in Hong Kong, Forthcoming in the International Journal of Human Resource Management.

21. Maguire, G. (2020). New survey shows the most pressing hiring problems facing SMEs 2020. HR Duo. https://www.hrduo.com/blog/new-surveyshows-the-most-pressing-hiring-problems-facing-smes-2020/.

22. Mullins, R., Yanqing Duan, David Hamblin , Phillip Burrell, Huan Jin Go uchowski Jerzy ,Ziemba Ewa, Billewicz Aleksander (2007) "A Web Based Intelligent Training System for SMEs", The Electronic Journal of e-Learning, Vol.5,No. 1,pp.39-48, www.ejel.org.

23. Omolo, J.W., Oginda, M.N. and Otengah, W.A. (2013) 'Influence of human resource management practices on the performance of small and medium enterprises in Kisumu Municipality, Kenya', International Journal of Business and Social Science, 2013,Vol. 4 No. 1.

24. Pranjali Singh, (2017). Impact of digitalization on small and medium enterprises in India. Paripex indian journal of research:Volume: 6 | Issue :4 | April 2017.

25. Press Information Bureau GOI, 22 JUL 2019 5:00PM by PIB Delhi. https://pib.gov.in/Pressreleaseshare.aspx?PRID=1579757

26. Puplampu, B. (2005) Toward a framework for understanding the distressed organisation - insights from practitioner r-based organisational interventions in an emerging economy. Consulting Psychology Journal: Practice and Research, 57(4):246-258.

27. Saini, D.S. and Budhwar, P.S. (2008) 'Managing the human resource in Indian SMEs:The role of indigenous realities', Journal of World Business, Vol. 43 No. 4 pp.417-434.

28. Sarita Satpathy, M.L.Nagajyothy and P. SailajaRani (2017), Issues And Challenges Of Micro, Small And medium Enterprises; An Explaratory Study Of Indian SMES. Indian Journal of Commerce and management (IJOCAM) volume 3 issue 6, June-2017,

29. Stefane M Kabene, Carole Orchard, John M Howard, Mark A Soriano and Raymond Leduc, (2006). The importance of human resources management in health care: a global context. Hum Resour Health. 2006; 4:20.Published online $2006 \mathrm{Jul} 27$.

30. The Economic Times, 26/02/2020, Trade in the time of Coronavirus: Sectors overdependent on Chinese imports face a grim reality.https://economictime s.indiatimes.com/small-biz/sme-sector/trade-in-the-time-of-coronavirussectors-overdependent-on-chinese-imports-face-a-grim-reality/articlesho $\mathrm{w} / 74312184 . \mathrm{cms}$

31. The Economics Times (Mar 05, 2020.) Trade impact of Coronavirus epidemic for India estimated at 348 million dollars: UN report .https://economictimes. indiatimes.com/news/economy/foreign-trade/trade-impact-ofcoronavirus-epidemic-for-india-estimated-at-348-million-dollars-unreport/articleshow/74487020.cms?from $=\mathrm{md}$ 
32. The Economics Times, (27/02/2020). Trade in the time of Coronavirus: Sectors overdependent on Chinese imports face a grim reality. https://economictimes.indiatimes.com/small-biz/sme-sector/tr ade-in-thetime-of-coronavirus-sectors-overdependent-on-chinese-imports-face-atime-of-coronavirus-sectors-overdependent-on-chin

33. The Financial Express. 29/05/2020, Why referral hiring has become key to smart hiring in India. https://www.financialexpress.com/money/whyreferral-hiring-has-become-key-to-smart-hiring-in-india/1185324/

34. The Ministry of Labour and Employment. Monday, March 23, 2020 https://economictimes.indiatimes.com/small-biz/sme-sector/tr ade-in-thetime-of-coronavirus-sectors-overdependent-on-chinese-imports-face-agrim-reality/articleshow/74312184.cms

35. UNIDO 2020. Guiding MSMEs' business recovery in the wake of the COVID19 pandemic | UNIDO. (2020), from https://www.unido.org/stories/guidingmsmes-business-recovery-wake-covid-19-pandemic

36. Upasna A Agarwal \&Sumi Jha (2015). Human Resource Practices in Indian SMEs - An Exploratory Study. 50(4), 16. The Indian Journal of Industrial relations Volume 50, no 4, April 2015

37. The Financial Express, $24 / 05 / 2020$. Covid-19 effect: Time for Made-in-India tag to go global. https://www.financialexpress.com/economy/covid-19effect-time-for-made-in-india-tag-to-go-global/1968616/

38. World Health Organization (2018), Managing epidemics: key facts about major deadly diseases ISBN 978-92-4-156553-0

39. Write, P. Gardner, T, Moynihan, L. and Allen, M. (2005). 'The Relationship between HR Practices and Firm Performance: Examining Causal Order.' Personnel Psychology, 58:409-46. 